\title{
Analisis Pengaruh Pembiayaan Bank Syariah, Belanja Pemerintah dan Pertumbuhan Ekonomi terhadap Tingkat Kemiskinan di Kota Ternate
}

\author{
Fadly $^{1)}$ Fathy Inat $^{2 *}$ Muhammad Iryanto ${ }^{3)}$ Cici Aryansi Quilim ${ }^{4}$ \\ ${ }^{\mathbf{1 , 2 , 3 , 4}}$ Fakultas Ekonomi dan Bisnis Islam, IAIN Ternate, Indonesia \\ *Email korespondensi: fathyinat@iain-ternate.ac.id
}

\begin{abstract}
Abstrak
Tujuan studi ini untuk menguji apakah ada korelasi signifikan antara pembiayaan bank syariah, belanja pemerintah fungsi pendidikan dan kesehatan, dan pertumbuhan ekonomi terhadap tingkat kemiskinan di Kota Ternate. Penelitian ini menggunakan teknik analisis regresi berganda dengan metode kuadrat terkecil (OLS). Observasi dimulai tahun 2011 hingga 2019. Hasil estimasi membuktikan bahwa ada korelasi negatif dan signifikan pada variabel IBF (Pembiayaan Bank Syariah) dan BP (Belanja Pemerintah Fungsi Pendidikan). Untuk variabel BK (Belanja Pemerintah Fungsi Kesehatan) meskipun memiliki korelasi negatif, namun belum signifikan mereduksi kemiskinan. Hasil berbeda terjadi pada pertumbuhan ekonomi $(G)$ yang secara teoritis akan menciptakan kesempatan kerja baru, secara empiris tidak memberikan manfaat langsung kepada kaum miskin, justru menambah jumlah orang miskin baru.
\end{abstract}

Kata kunci: kemiskinan, pembiayaan, belanja pemerintah, pertumbuhan ekonomi

\begin{abstract}
Analysis of Islamic Banking Financing, Government Expenditure, and Economic Growth Effect on Poverty Levels in Ternate City-The purpose of this study is to examine whether there is a significant correlation between Islamic banking financing, government spending on education and health functions, and economic growth on poverty rate in Ternate City. This study uses multiple regression analysis techniques with the Ordinary Least Squares (OLS) method. Observations began in 2011 to 2019. The estimation results prove that there is a negative and significant correlation in the variables IBF (Islamic Bank Financing) and BP (Government Expenditures for Education Function). For BK variable (Government Expenditures for Health Function), although it has a negative correlation, it has not significantly reduced poverty. A different result occurs in economic growth $(G)$, which theoretically will create new job opportunities, empirically, it does not provide direct benefits to the poor, even increases the number of new poor people.
\end{abstract}

Keywords: poverty, Islamic banking financing, government expenditure, economic growth

Saran sitasi: Fadly., Inat, F., Iryanto, M., \& Quilim, C. A. (2021). Analisis Pengaruh Pembiayaan Bank Syariah, Belanja Pemerintah dan Pertumbuhan Ekonomi terhadap Tingkat Kemiskinan di Kota Ternate. Jurnal Ilmiah Ekonomi Islam, 7(01), 123-129. doi:http://dx.doi.org/10.29040/jiei.v7i1.1858

DOI: http://dx.doi.org/10.29040/jiei.v7i1.1858

\section{PENDAHULUAN}

Sejak tahun 2011 hingga 2016 terjadi tren penurunan tingkat kemiskinan di Kota Ternate. Namun, tiga tahun berikutnya, angka kemiskinan mengalami kenaikan signifikan, dari 2,67\% pada tahun 2017 bertambah menjadi 3,14\% pada tahun 2019. Artinya, terdapat 7.250 jiwa warga Kota Ternate yang terpaksa bertahan hidup dengan pengeluaran kurang dari Rp.578.180 per bulan. Fenomena ini membawa keprihatinan sekaligus catatan penting di tengah komitmen global untuk mewujudkan dunia tanpa kemiskinan pada tahun 2030 yang dideklarasikan dalam SDGs/Tujuan Pembangunan Berkelanjutan. 
Jurnal Ilmiah Ekonomi Islam, 7(01), 2021, 124

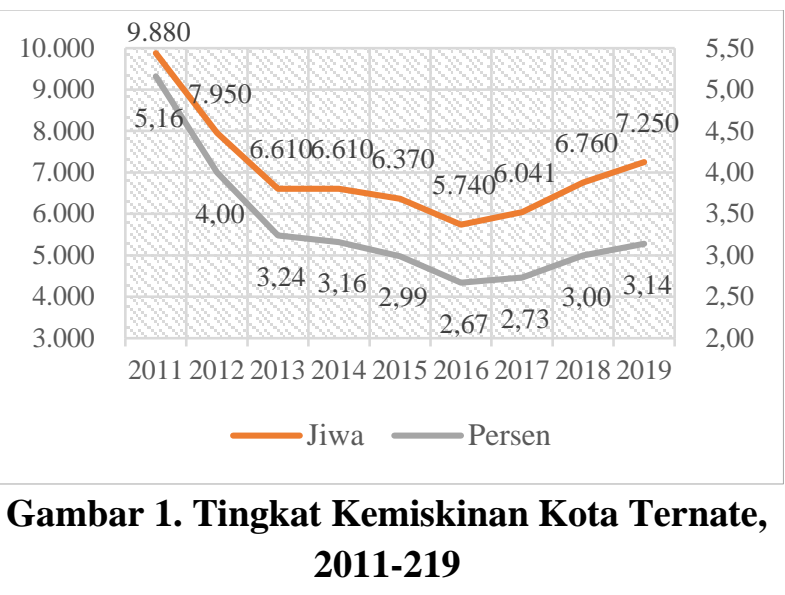

Sumber: BPS Kota Ternate, 2020 (diolah)

Al-Quran menyebut faqir-miskin sebagai orang yang tak berdaya dalam memenuhi kebutuhan hidupnya, dan wajib ditolong karena setiap manusia memiliki hak atas penghidupan yang layak. Quraish Shihab (1996) menjelaskan dalam Tafsir Maudhu'inya, kata "Faqir" berasal dari kata "faqr" berarti tulang punggung. "Faqir" adalah orang yang patah tulang punggungnya akibat beratnya beban yg harus dipikul. Kata miskin terambil dari kata "sakana" yang berarti diam atau tenang, yang bermakna sikap berdiam diri, enggan, atau tidak dapat bergerak dan berusaha.

Sejumlah riset yang mempelajari fenomena kemiskinan modern sampai pada kesimpulan bahwa kemiskinan adalah problem multidimensional ketakberdayaan mencapai hidup secara layak. Ketidakberdayaan itu hasil dari tatanan ekonomi yang terlalu timpang dan liberal (lihat Seabrook, 2006; Sen, 2000; Todaro \& Smith, 2011; World Bank, 2015), yang merampas kapabilitas manusia dengan menutup akses pada sumber daya kehidupan. Kenyataan ini oleh Amartya Sen disebut sebagai capability deprivation.

Karenanya, ikhtiar penanggulangan kemiskinan juga mesti bersifat multidimensi atau lintas sektor, dengan ciri utama memuat unsur perlindungan dan pemberdayaan. Instrumen kebijakannya ada dalam pengeluaran pemerintah-merujuk pada lingkaran setan kemiskinan (vicious cycle of poverty) Nurkse dan anjuran dari J.M. Keynes tentang perlunya belanja pemerintah untuk mengintervensi pasar-karena terdapat belanja yang secara natural bersentuhan langsung dengan ikhtiar mengentaskan miskinan. Antara lain, belanja kesehatan dan pendidikan (Sen, 2006; Sepulveda \& Martinez-Vazquez, 2011; Todaro \& Smith, 2011). Dengan belanja ini, kaum miskin akan mendapat proteksi lewat kemudahan memperoleh kesehatan dan pendidikan yang berkualitas yang sulit disediakan pasar. Syarat utamanya adalah desain anggran bersifat pro-poor.

Para ahli lintas zaman telah menekankan hal ini, bahkan dalam Islam sistem nilainya sangat komprehensif dan secara operasional telah dipraktikkan dengan begitu hebat oleh Nabi saw. Baitul-maal sebagai term keuangan publik diorganisir oleh Nabi saw dengan prioritas belanja untuk memenuhi kebutuhan kaum lemah (Chapra, 2000; Mannan, 1995)

Di sisi lain, kehadiran bank Islam memberikan harapan baru dalam usaha mereduksi kemiskinan. Secara konseptual fungsi intermediasi pada bank syariah akan berjalan lebih efektif dan sehat sebagai konsekuensi pelarangan bunga dan praktik spekulatif (Elhachemi \& Othman, 2015; Mannan, 1995): dana akan mengalir ke sektor riil yang secara statistik didominasi oleh pelaku usaha berskala mikro dan kecil (UMK), sehingga akan lebih menjangkau kum miskin. Bank Islam juga menyediakan akses khusus bagi kaum miskin lewat produk Qardul-hasan.

Studi ini bermaksud mempelajari dampak dari kehadiran bank syariah terhadap ikhtiar penanggulangan kemiskinan di Kota Ternate. Juga, bagaimana pengaruh yang ditimbulkan dari belanja pemerintah dan pertumbuhan ekonomi yang selama ini diyakini dapat mereduksi kemiskinan. Untuk itu, pendekatan analisis menggunakan metode OLS yang akan menguji secara empiris apakah terdapat korelasi antara variabel independen (pembiayaan bank syariah, belanja pemerintah fungsi pendidikan dan kesehatan, dan pertumbuhan ekonomi) terhadap tingkat kemiskinan di Kota Ternate dalam kurun waktu 2011 hingga 2019.

\section{METODE PENELITIAN}

Metode penelitian yang digunakan adalah metode kuantitatif dengan alat analisis regresi liner berganda. Analisis regresi berkenan dengan studi ketergantungan satu variabel dengan variabel lainnya yang mengambarkan pengaruh hubungan antara variabel yang diteliti (Gujarati, 1995; Widarjono $\mathrm{Ph} . \mathrm{D}, 2016)$. Teknik analisis menggunakan metode kuadrat terkecil (OLS/ordinary least squares). Model umum penelitian adalah; $\mathrm{PV}=\mathrm{f}(\mathrm{IBF}, \mathrm{BP}, \mathrm{BK}$, dan $\mathrm{G})$. Selanjutnya, dari model umum tersebut diformulasikan ke dalam bentuk persamaan ekonometrik menjadi; 


$$
\begin{gathered}
\mathrm{PV}=\beta_{0}+\beta_{1} \ln (\mathrm{IBF})+\beta_{2} \ln (\mathrm{BP})+\beta_{3} \ln (\mathrm{BK})+\beta_{4} \mathrm{G} \\
+\mathrm{e}
\end{gathered}
$$

Keterangan notasi:

$\mathrm{PV}=$ Tingkat kemiskinan/Head Count (\%)

$\mathrm{IBF} \quad=$ Pembiayaan bank syariah (BUS \& BPRS) (Rp. Miliar)

$\mathrm{BP}=$ Belanja pemerintah fungsi pendidikan $(\mathrm{Rp}$. Miliar)

BK = Belanja pemerintah fungsi kesehatan (Rp. Miliar)

$\mathrm{G}=$ Pertumbuhan ekonomi $(\%)$

$\mathrm{e} \quad=$ Residual

$\beta_{0,1,2,3,4}=$ Koefisien

$\mathrm{Ln} \quad=$ Logaritma natural

$\mathrm{f} \quad=$ fungsi

Variabel dependen penelitian ini adalah tingkat kemiskinan (PV) dengan indikator head count/jumlah orang miskin dalam satuan persen. Indikator ini menjadi ukuran resmi Badan Pusat Statistik (BPS) dalam mengukur kemiskinan di Indonesia yang berbasis pada konsep kemiskinan absolut: seseorang dikategorikan miskin bila jumlah pengeluaran untuk memenuhi kebutuhan dasarnya (basic need) kurang dari standar terminimal/garis kemiskinan. BPS memformulasikan garis kemiskinan (GK) terdiri dari komponen makanan (GKM) dan non-makanan $(\mathrm{GKNM})$, sehingga GK $=\mathrm{GKM}+\mathrm{GKNM}$. Garis kemiskinan makanan (GKM) merupakan nilai pengeluaran kebutuhan minimum makanan yang disetarakan dengan 2.100 kilokalori per kapita per hari, diwakili oleh 52 jenis komoditi. Garis kemiskinan non-makanan (GKNM) adalah kebutuhan minimum untuk perumahan, sandang, pendidikan, dan kesehatan (BPS, 2020)

Sementara itu, variabel independen terdiri dari: (1) pembiayaan bank syariah (IBF), adalah total pembiayaan Bank Umum Syariah (BUS) dan Bank Pembiayaan Syariah (BPRS) yang beroperasi di Kota Ternate, dalam satuan miliar Rupiah, (2) realisasi belanja pemerintah fungsi pendidikan (BP) dan (3) kesehatan (BK) dalam satuan miliar Rupiah, serta (4) pertumbuhan ekonomi $(\mathrm{G})$ dalam satuan persen.

Sumber data bersifat sekunder yang diperoleh dari publikasi resmi dari Badan Pusat Statistik (BPS), Otoritas Jasa Keuangan (OJK), BPKAD Kota Ternate, dan Bank Indonesia (BI) serta sumber-sumber data pendukung lainnya. Data yang digunakan adalah data time series (deret waktu) mulai tahun 2011.q1 hingga 2019.q4.

\section{HASIL DAN PEMBAHASAN}

\subsection{Hasil Penelitian}

Hasil estimasi menunjukkan bahwa koefisien determinasi $\mathrm{R}^{2}$ (Adjusted $R$ Squared) bernilai 0.925703. Angka ini menjelaskan kelayakan empiris model penelitian. Maknanya adalah, perubahan tingkat kemiskinan di Kota Ternate 92\% nya dipengaruhi oleh semua variabel independen dalam model. Sisanya sebesar $8 \%$ dijelaskan oleh variabel lain di luar model.

Dependent Variable: PV

\section{Tabel 1. Hasil Regresi}

Method: Least Squares, Sample: 2011Q1 2019Q4, Included observations: 36

HAC standard errors \& covariance (Bartlett kernel, Newey-West fixed bandwidth $=4.0000$ )

\begin{tabular}{lrrrc}
\hline Variable & Coefficient & Std. Error t-Statistic & Prob. \\
\hline C & 20.20237 & 2.493705 & 8.101346 & 0.0000 \\
LOG(IBF) & -0.723893 & 0.398101 & -1.818366 & 0.0787 \\
LOG(BP) & -2.513068 & 0.535645 & -4.691669 & 0.0001 \\
LOG(BK) & -0.424153 & 0.612385 & -0.692625 & 0.4937 \\
$\quad$ G & 0.295742 & 0.087845 & 3.366630 & 0.0020 \\
\hline R-squared & 0.934194 & Mean dependent var & 3.401250 \\
Adjusted R- & & & \\
squared & 0.925703 & S.D. dependent var & 0.753864 \\
S.E. of & & & \\
regression & 0.205485 & Durbin-Watson stat & 0.318098 \\
F-statistic & 110.0203 & Prob(F-statistic) & 0.000000 \\
\hline Suri
\end{tabular}

Sumber: Olah data (Eviews9)

\section{Uji F (Kelayakan Model)}

Pengujian F digunakan untuk melihat signifikansi semua variabel independen dalam mempengaruhi variabel dependen. Hasil estimasi membuktikan bahawa nilai Prob(F-Statistic) 0.000000 , lebih kecil dari alpha $=5 \%$ (0.05) sehingga dapat diterjemahkan bahwa model regresi yang diestimasi dalam penelitian ini layak digunakan. Dengan kata lain, semua variabel independen (IBF, BP, BK, G) secara bersama-sama terbukti mempengaruhi variabel dependen (tingkat kemiskinan di Kota Ternate).

\section{Uji t (Parsial)}

Koefisien variabel pembiayaan bank syariah (IBF) adalah -0.723893 dengan nilai prob. (0.0787) lebih kecil dari alpha $=10 \%$ (0.1). Maknanya, pada derajat signifikansi $90 \%$ terdapat korelasi negatif atau hubungan terbalik antara variabel IBF dengan variabel PV. Bila terjadi penemabahan pembiayaan sebesar 1 persen, maka akan mengurangi tingkat kemiskinan sebesar 0.72 persen. Hubungan yang sama terjadi juga 
pada variabel belanja pendidika (BP) dengan koefisien sebesar -2.613068 dan nilai prob. (0.0001) lebih kecil dari alpha $=1 \%$ (0.01). Artinya, bila terjadi peningkatan belanja pemerintah fungsi pendidikan sebesar 1 persen, maka dapat menurunkan tingkat kemiskinan sebesar 2.61 persen.

Variabel belanja kesehatan meskipun bertanda negatif namun tidak signifikan. Sementara itu, variabel pertumbuhan ekonomi berkorelasi positif dan signifikan pada alpha $=5 \%$ (0.05). Maknanya, peningkatan pertumbuhan eknomi sebesar 1 persen akan mendorong naiknya tingkat kemiskinan sebesar 0.29 persen. Seluruh interpretasi ini mengasusmsikan keadaan lain tak berubah (cateris paribus)

\section{Uji Asusmsi Klasik}

Hasil pengujian Varience Inflation Factor (VIF) untuk mendeteksi multikolinieritas mengindikasikan terdapat satu variabel (BK) yang memiliki nilai di atas 10. Sementara variabel lainnya (IBF, BP dan G) bernilai lebih kecil dari 10. VIF mensyaratkan terbebas multikolinieritas jika nilai Centered VIF tidak melebihi angka 10 (Tabel 2). Meski begitu, Gujarati (1995) dan Widarjono Ph.D (2016) menegaskan bahwa model yang terdeteksi multikolinieritas masih tetap bisa digunakan dan estimator yang dihasilkannya tetap tidak bias, linier dan tetap mempunyai varian yang minimum (BLUE).

\section{Tabel 2. Multikolinieritas}

Variance Inflation Factors

Sample: 2011Q1 2019Q4, Included

observations: 36

\begin{tabular}{cccc}
\hline \hline & Coefficient & Uncentered & Centered \\
\hline \hline Variable & Variance & VIF & VIF \\
\hline \hline C & 6.218565 & 3721.585 & NA \\
LOG(IBF) & 0.158484 & 2742.036 & 9.762238 \\
LOG(BP) & 0.286915 & 5041.002 & 1.960682 \\
LOG(BK) & 0.375015 & 3435.832 & 13.06880 \\
G & 0.007717 & 285.6398 & 1.543317 \\
\hline \hline
\end{tabular}

Sumber: Olah data (Eviews9)

Uji Heteroskedastis dengan teknik Hervey maupun Breusch-Pagan-Godfrey menghasilkan semua nilai Prob. tidak signifikan karena lebih besar dari alpha $=5 \%$ (0.05). Hasil ini mengindikasikan bahwa model penelitian terbesas dari masalah heteroskedastisitas (Tabel 3). Selanjutnya, hasil estimasi mengindikasikan terdapat masalah outokorelasi, diindikasikan melalui nilai DW (DurbinWatson Stat) yang kecil. Tentunya, otokorelasi menyebabkan sifat BLUE dalam metode OLS tidak berfungsi. Akibatnya, uji t serta uji F tidak valid atau tidak bisa dipercaya lagi. Untuk mengatasi hal ini, perlu melakukan tindakan perbaikan, salah satunya lewat metode Newey, Whitney dan Kenneth (HAC/Newey-West). Widarjono Ph.D (2016) menjelaskan, Metode HAC memberikan standard error yang konsisten, sehingga evaluasi terhadap uji t dan uji $\mathrm{F}$ bisa dilakukan meskipun ada masalah outokorelasi (lihat Tabel 3)

\section{Tabel 3. Heteroskedastis}

Heteroskedasticity Test: Harvey

\begin{tabular}{lrll|}
\hline \hline F-statistic & 1.592256 Prob. F(4,31) & 0.2011 \\
Prob. Chi- & \\
Obs*R-squared & 6.135692 & $\begin{array}{l}\text { Square(4) } \\
\text { Prob. Chi- }\end{array}$ & 0.1892 \\
$\begin{array}{l}\text { Scaled explained } \\
\text { SS }\end{array}$ & 3.840336 & Square(4) & 0.4280 \\
\hline \hline
\end{tabular}

Heteroskedasticity Test: Breusch-Pagan-Godfrey

\begin{tabular}{lccc}
\hline \hline F-statistic & 2.154378 & $\begin{array}{c}\text { Prob. F(4,31) } \\
\text { Prob. Chi- }\end{array}$ & 0.0976 \\
Obs*R-squared & 7.830639 & $\begin{array}{c}\text { Square(4) } \\
\text { Prob. Chi- }\end{array}$ & 0.0980 \\
Scaled explained & 3.426753 & Square(4) & 0.4891 \\
SS & &
\end{tabular}

Sumber : Olah data (Eviews9)

Uji normalitas juga mengindikasikan data terdistribusi seacara normal karena nilai prob $J B$ berada di atas alpha 0,05 (Gambar 2). Dengan demikian, setelah mengikuti prosedur yang disyaratkan dalam metode OLS, maka hasil regresi metode OLS dalam penelitian ini tetap memiliki sifat BLUE sehingga interpretasi terhadap uji $t$ dan uji $F$ bersifat valid dan tidak bias.

\section{Gambar 2. Uji Normalitas}

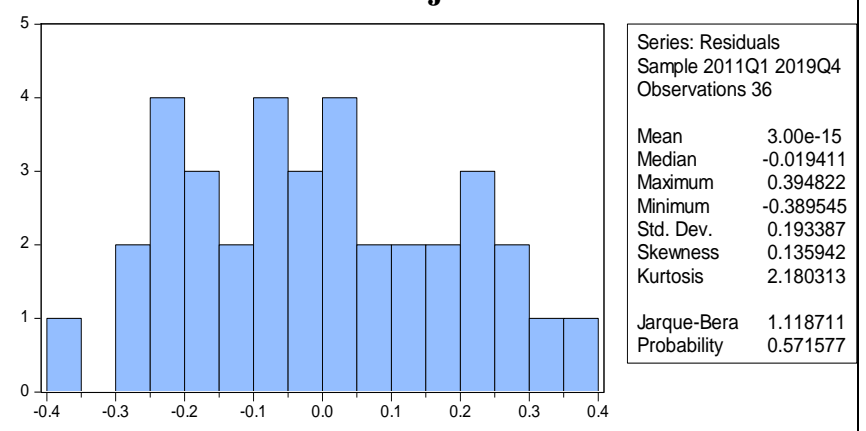

Sumber: Olah data (Eviews9) 
Jurnal Ilmiah Ekonomi Islam, 7(01), 2021, 127

\subsection{Pembahasan}

Per Desember 2019, terdapat 5 bank syariah yang beroperasi di Kota Ternate; 3 Bank Umum Syariah/BUS (Bank Muamalat, Bank Syariah Mandiri/BSM, dan BNI Syariah), dan 2 Bank Pembiayaan Rakyat Syariah/BPRS (BPRS Bahari Berkesan dan BPRS Bobato Lestari). Bank Muamalat adalah bank syariah pertama di Kota Terante, mulai beroperasi pada tahun 2004. Kegiatan bisnis lima bank ini telah memberikan efek langsung yang signifikan dalam mengurangi kemiskinan di Kota Ternate. Bahkan dengan pangsa pasar pembiayaan yang sangat terbatas, hanya 5 persen dari total dana yang disalurkan perbankan di provinsi Maluku Utara. Kenyataan ini mengkonfirmasi applicable-nya fungsi sosio-ekonomi bank syariah dalam mewujudkan tujuan kemaslahatan.

Tohirin \& Husaini (2019) juga menemukan hasil serupa di tingkat nasional, bahwa pembiayaan bank syariah memberikan manfaat pada kaum miskin, bahkan pengaruhnya lebih kuat dibandingkan kredit pada bank konvensional. Sementara studi yang dilakukan Iskandar \& Possumah (2018) menemukan wilyah dengan indeks inklusifitas keuangan syariah (ISFI/Index of Syariah Financial Inclusion) yang tinggi cenderung lebih mampu menekan angka kemiskinan.

Lebih lanjut, sistem bagi hasil dan pelarangan spekulasi menciptakan stabilitas sistem keuangan dan meredam inflasi pada level rendah sehinga menjadikan perekonomian lebih resilienc (Hossain, 2016). Inflasi yang tinggi menambah beban bagi kaum miskin sekaligus mencipatkan kemiskinan baru, karena kelompok rentan yang hidup sedikit di atas garis kemiskinan akan jatuh di bawah garis kemiskinan.

Tabel 4. Indikator Kemiskinan, Belanja Pemerintah dan Pertumbuhan Ekonomi Kota

\begin{tabular}{lccc}
\multicolumn{4}{c}{ Terante } \\
\hline Deskripsi & $\mathbf{2 0 1 1}$ & $\mathbf{2 0 1 5}$ & $\mathbf{2 0 1 9}$ \\
\hline $\begin{array}{l}\text { Garis } \\
\text { Kemiskinan (Rp) }\end{array}$ & 361.752 & 459.551 & 578.180 \\
\hline $\begin{array}{l}\text { Pembiayaan } \\
\text { Bank Syariah } \\
\text { (Rp. Miliar) }\end{array}$ & 123,00 & 189,00 & 495,00 \\
\hline $\begin{array}{l}\text { Pertumbuhan } \\
\text { Ekonomi (\%) }\end{array}$ & 9,65 & 8,09 & 8,25 \\
\hline $\begin{array}{l}\text { Total Belanja } \\
\text { Pemerinta (Rp. } \\
\text { Miliar) }\end{array}$ & 527.081 & 831,370 & $1.079,155$ \\
\hline
\end{tabular}

\begin{tabular}{llll}
\hline Deskripsi & $\mathbf{2 0 1 1}$ & $\mathbf{2 0 1 5}$ & $\mathbf{2 0 1 9}$ \\
\hline $\begin{array}{l}\text { Fungsi } \\
\text { Pendidikan (Rp. }\end{array}$ & 195,00 & 311,00 & 221,38 \\
Miliar) & & & \\
\hline Fungsi & 31,00 & 56,00 & 75,72 \\
Keseahatan (Rp. & & & \\
Miliar) & & & \\
\hline
\end{tabular}

Sumber: BPS Kota Ternate, BPKAD Kota Ternate, SPS-OJK, (2019)

Belanja fungsi pendidika terbukti secara empiris berpengaruh menurukan tingkat miskin. Hal ini mengisyaratkan belanja tersebut telah mampu membuka akses kaum miskin pada pendidikan. Sejumlah studi yang mendalami subjek ini juga menemukan hasil serupa, bahwa belanja pendidikan telah menjadi investasi publik dan mendorong peningkatan human capital, dan produktivitas (Fan et al., 2002; Todaro \& Smith, 2011; Sepulveda \& Martinez-Vazquez, 2011), serta secara lebih esensial, membuka kesempatan bagi kaum miskin untuk mengembangankan diri (human capability), tidak hanya aspek ekonomi tapi juga pada aspek kehidupan lainnya (Sen, 2000). Fakta ini ditemukan di banyak negara di dunia, seperti Jepang, China dan negaranegara di Eropa.

Selama masa observasi, belanja pendidikan mengambil porsi besar, rata-rata di atas 30 persen dari total belanja APBD Kota Ternate (Tabel 4). Mulai tahun 2016, Bantuan Operasional Sekolah Daerah (BOSDA) untuk tingkat pendidikan dasar direalisasikan dalam APBD. Kebijakan ini kian memperkuat efek perluasan akses sekaligus menjamin keberlanjutan warga kota memperoleh pendidikan dasar dan menengah, yang sejak tahun 2011 telah mencapai angka rata-rata lama sekolah 10,53 tahun, dan di tahun 2019 meningkat menjadi 11,29 tahun (BPS Kota Ternate, 2020). Artinya, seluruh warga kota usia sekolah telah mengenyam pendidikan dasar (SD hingga SMP), sementara tingkat SMA baru mencapai angka $83,01 \%$.

Konsistensi belanja penidikan pro-poor dengan penekanan pada perluasan akses dan peningkatan kualitas pendidikan, hasilnya akan terlihat dalam jangka panjang: mengembalikan capability yang hilang, mengurangi kemiskinan, dan menciptakan kesejahteraan bersama di Kota Ternate.

Untuk belanja fungsi kesehatan, studi ini memperlihatkan hasil berbeda dalam hal signifikansinya. Meskipun sifat alamiyah dari belanja 
ini tetap terbukti dapat membantu kaum miskin (bertanda negatif), namun belum signifikan untuk kurun waktu 2011-2019. Temuan ini mengisyaratkan pemanfaatan anggaran belum terlalu tepat sasaran (tidak pro-poor). Faktanya, sampel belanja kesehatan tahun 2014 menunjukkan hanya 30 persen (Rp. 14,2 Miliar) dari total belanja fungsi kesehatan dialokasikan pada pos belanja langsung/belanja publik, dan $70 \%$ nya untuk belanja tidak langsung yang lebih berorientasi pada belanja aparatur/pegawai. Sementara secara total, belanja fungsi kesehatan hanya mengambil porsi rata-rata 6,5 persen dari total APBD Kota Ternate (Tabel 4). Artinya, masih belum memenuhi persyaratan Undang-Undang Kesehatan Nomor 36/2009 yang secara tegas menyebutkan batas minimum anggaran kesehatan adalah $10 \%$ (di luar gaji) dari total APBD. Boleh jadi, kecilnya anggaran kesehatan ini mengawetkan hambatan-hambatan klasik seperti rendahnya mobilitas tenaga kesehatan dan keterbatasan fasilitas kesehatan, sehingga pelayanan kesehatan tak mampu menjangkau kaum miskin secara layak.

Selanjutnya, hasil estimasi variabel pertumbuhan ekonomi mengindikasikan hubungan searah (bertanda positif) dengan tingkat kemiskinan. Secara teoritis, pertumbuhan ekonomi menjelaskan bahwa perekonomian yang mampu meningkatkan out-put agregatnya akan menciptakan lebih banyak kesempatan kerja. Semakin tinggi pertumbuhan, maka akan meningkatkan tingkat pendapatan rata-rata penduduk. Hingga kini, indikator pertumbuhan masih digunakan untuk mengukur kinerja ekonomi suatu negara. Meskipun dalam banyak kasus pertumbuhan ekonomi bukan lagi indikator kuat untuk menilai kesejahteraan tapi hanya menunjukkan tingkat kekayaan dan produktivitas, dan menjadi bahan evaluasi dalam mewujudkan pembangunan yang lebih merata dan manusiawi.

Temuan studi ini membuktikan hal itu, bahwa Produk Domestik Regional Bruto (PDRB) Kota Ternate yang tiap tahun bertumbuh rata-rata $8,3 \%$ justru hanya menambah jumlah orang miskin. Bappenas (2015) menemukan gejala hight-growth, less-pro job and less-pro poor: pertumbuhan ekonomi Kota Ternate yang tinggi tidak memberikan dampak terhadap pengurangan kemiskinan. Pertumbuhan ekonomi seperti ini cenderung tidak memihak kaum lemah, hanya menambah kekayaan kelompok yang sudah makmur, dan tentu kian memperlebar ketimpangan sosial-ekonomi.

\section{KESIMPULAN}

Tujuan penelitian ini adalah menguji apakah terdapat korelasi signifikan antara pembiayaan bank syariah (IBF), belanja pemerintah fungsi pendidikan (BP) dan kesehatan (BK), serta pertumbuhan ekonomi (G) terhadap tingkat kemiskinan di Kota Ternate. Hasil estimasi dengan menggunakan metode OLS membuktikan bahawa ada korelasi negatif dan signifikan pada variabel IBF dan BP. Untuk Variabel BK meskipun memiliki korelasi negatif terhadap tingkat kemiskinan namun belum signifikan mereduksi kemiskinan. Hasil berbeda terjadi pada pertumbuhan ekonomi-secara teoritis akan menciptakan kesempatan kerja baru yang akan berdampak pada penurunan kemiskinan-secara empiris tidak memberikan manfaat langsung kepada kaum miskin, justru menambah jumlah orang miskin baru.

Dengan demikian, sebagai ikhtiar mereduksi kemiskinan di Kota Ternate, studi ini memberikan catatan bahwa penting bagi bank syariah untuk meningkatkan dana pihak ketiga agar pembiayaan perbankan syariah kepada kelompok yang berada di bawah garis kemiskinan dapat diperluas dan selanjutnya menjangkau kelompok rentan yang berada sedikit di atas garis kemiskinan. Di samping itu, desain hingga implementasi belanja pemerintah yang bersifat pro-poor harus diaplikasikan secara konsisten, karena hal ini juga akan membawa dampak langsung pada pertumbuhan ekonomomi yang berkualitas: merepresentasikan keberpihakan pada kaum miskin dan berkelanjutan. "Dan pada hartaharta mereka ada hak untuk orang miskin yang meminta dan orang miskin yang tidak mendapat bagian (tidak meminta)”. (QS. al-Zariyat, 51:19)

\section{REFERENSI}

Bappenas. (2015). Seri Analisis Pembangunan Wilayah Provinsi Maluku Utara 2015.

BPS Kota Ternate. (2020). Statistik Daerah Kota Ternate Tahun 2020.

BPS Maluku Utara. (2020). Profil Kemiskinan Provinsi Maluku 2019. In Badan Pusat Statistik Maluku Utara.

Chapra, M. U. (2000). Sistem Moneter Islam. Gema Insani Press, Jakarta \& Tazkia Cendikia. 
Jurnal Ilmiah Ekonomi Islam, 7(01), 2021, 129

Elhachemi, H. G., \& Othman, M. A. (2015). Empirical Analysis on the Nexus Between Islamic Banking Development in Terms of Size and Activity, Economic Growth and Financial Crisis in Islamic Republic of Iran. International Journal of Scientific Research and Innovative Technology, 2(6), 27-44.

Fan, S., Zhang, L., \& Zhang, X. (2002). Growth, inequality, and poverty in rural China. International Food Policy Research Institute (IFPRI), June 2014. http://www.ifpri.org/publication/growthinequality-and-poverty-rural-china

Gujarati, D. (1995). Ekonometrika Dasar. Penerbit Erlangga, Jakarta.

Hossain, A. A. (2016). Inflationary shocks and real output growth in nine Muslim-majority countries: Implications for Islamic banking and finance. Journal of Asian Economics, 45, 56-73. https://doi.org/10.1016/j.asieco.2016.06.004

Iskandar, A., \& Possumah, B. T. (2018). Inklusifitas Keuangan Syariah dan Kemiskinan di Indonesia. Nukhbatul 'Ulum, 4(2), 1-18. https://doi.org/10.36701/nukhbah.v4i2.38
Mannan, M. A. (1995). Teori dan Praktek Ekonomi Islam (D. Drs H.M. Sonhadji (ed.)). PT Dana Bakti Wakaf, Yogyakarta.

Seabrook, J. (2006). Kemiskinan Global, Kegagalan Model Ekonomi Neoliberalisme. Resist Book.

Sen, A. (2000). Demokrasi Bisa Memberantas Kemiskinan. Mizan.

Sepulveda, C. F., \& Martinez-Vazquez, J. (2011). The Consequences of Fiscal Decentralization on Poverty and Income Equality. Environment and Planning C: Government and Policy, 29(2), 321343. https://doi.org/10.1068/c1033r

Todaro, M. P., \& Smith, S. C. (2011). Pembangunan Ekonomi (11th ed.). Penerbit Erlangga, Jakarta.

Tohirin, A., \& Husaini, F. (2019). Does Islamic Banking Financing Help the Poor? International Accounting, Business \& Economics, 1955, 4150.

Widarjono Ph.D, A. (2016). Ekonometrika: Pengantar \& Aplikasinya. UPP STIM YKPN, Yogyakarta.

World Bank. (2015). Ketimpangan Yang Semakin Lebar, Ringkasan Eksekutif. 